\title{
Growth Patterns and Biomass Relations of Xanthocephalum sarothrae (Pursh) Shinners on Sandy Soils in Southern New Mexico
}

\author{
SAMU NADABO, REX D. PIEPER, AND RELDON F. BECK
}

\begin{abstract}
Growth patterns of broom snakeweed were studied on three areas of sandy range sites in southern New Mexico by measuring plant canopy biweekly during the growing season and calculating canopy volume. Canopy volume increased during the summer of 1977 on all three study areas. In 1978, canopy volume declined throughout much of the growing season because effective rainfall came late in the season. More than $60 \%$ of the canopy biomass was contributed by brown stems and leaves, about $30 \%$ by green leaves and stems, and less than $10 \%$ by inflorescences on most dates. Coefficients of determination relating canopy volume to canopy biomass were less than 0.70 . Growth forms and patterns were quite variable among the populations studied.
\end{abstract}

Broom snakeweed (Xanthocephalum sarothrae [Pursh] Shinners), generally considered an undesirable range species, is widely distributed over the western United States. It extends from Canada in the north to Mexico in the south, and from California valleys in the west to the plains of Kansas, Oklahoma, and Nebraska in the east (Range Plant Handbook 1937; Kingsbury 1964; Correll and Johnston 1970; Schmutz and Little 1970). Presently, millions of hectares of West Texas, New Mexico, and adjacent states were occupied by dense stands of broom snakeweed (Ueckert and Foster 1976).

Two problems with broom snakeweed on rangelands are: (1) as a poisonous plant and (2) as a competitive range weed. Livestock losses attributable to broom snakeweed and related forms in Texas have been estimated at 2 to 3 million dollars annually (Dollahite and Anthony 1957). Symptoms associated with snakeweed poisoning are abortion or premature birth of weak calves and other reproductive disturbances. The toxic agent has been identified tentatively as a saponin (Dollahite et al. 1962 and Kingsbury 1964), although species of the genus also accumulate selenium (Hamilton and Beath 1963).

\footnotetext{
Authors are former graduate student, professor, and associate professor, Department of Animal and Range Sciences, New Mexico State University, Las Cruces, NM 88003 .

This report is Journal article 753, Agricultural Experiment Station, New Mexico State University, Las Cruces.

Manuscript received February 10, 1979.
}

For many years, broom snakeweed has been considered an indicator of poor range condition (Campbell and Bomberger 1934; Pieper 1967). Talbot (1926) concluded that the best indicators of late stages of range deterioration in southern New Mexico on upland range sites were dropseed grasses (Sporobolus spp.), leatherweed (Croton spp.), silver leaf nightshade (Solanum eleagnifolium cav), and creosotebush (Larrea tridentata [DC] Cov) followed by broom snakeweed. However, Jameson (1970) reported on a 13-year study which showed that broom snakeweed was not an indicator of poor range condition on southwestern pinyonjuniper ranges. His results indicated that snakeweed populations oscillated in a cyclic pattern and were not necessarily related to range condition.

Although some work has been done on relations between herbage production and snakeweed density (Ueckert 1979), little information is available on seasonal growth patterns of broom snakeweed. The objectives of this study were to determine seasonal changes in volume and biomass of snakeweed canopies and to determine biomass allocation among plant parts.

\section{Description of Study Area}

New Mexico State University Agricultural Experiment Station Ranch is on the Jornada Plain about $32 \mathrm{~km}$ north of Las Cruces, New Mexico. Topography is nearly level-to-gently undulating uplands, interspersed with swales and old lake beds (Herbel et al. 1970). The area is bounded by the San Andres Mountains on the east, and by the Rio Grande Valley on the west. The Dona Ana Mountains are located on the southeastern part of the University Ranch. Elevations vary from 1,190 to $1,372 \mathrm{~m}$. Soils of the area range from deep loamy sands to clays. Those on the study areas are in the Simona-Harrisburg complex.

Vegetation on nearly level, good-condition sandy sites consists largely of black grama (Bouteloua eriopoda Torr.), dropseeds (Sporobolus spp.) and three awns (Aristida spp.) in varying proportions, with black grama always predominant. Depleted ranges have been invaded by brush and forbs. Most broom snakeweed plants on the Experimental Ranch died during 1974 when climatic conditions were very dry. Most plants on study plots became 
established since then.

Climate is arid and extreme weather fluctuations are characteristic of this area for centuries (Buffington and Herbel 1965). Temperatures are moderate with a yearly mean of about $16^{\circ} \mathrm{C}$. Wide range in day and night temperatures exists throughout the year, and relative humidity is characteristically low (Paulsen and Ares 1962). The warmest months are usually June and July.

Departures from long-term average precipitation are frequent and fluctuations in seasonal and annual amounts are extreme (Paulsen and Ares 1961). Annual precipitation on the Experimental Ranch in 1977 varied from $189 \mathrm{~mm}$ at one experimental area to $254 \mathrm{~mm}$ at another, less than $5 \mathrm{~km}$ away, both having long-term averages of about $220 \mathrm{~mm}$. Summer precipitation is characterized by convectional thunderstorms, usually localized, scattered and violent in nature, while frontal storms occur in winter. The growing season is usually from about July 1 to September 30 . Of the average annual precipitation, almost $120 \mathrm{~mm}$ or over $53 \%$ falls during the growing season. In 1977 Experimental Areas II and III received above-average annual rainfall. Both the growing season and annual precipitation were below average on Experimental Area I. In 1978, however, only Area II received below-average precipitation during the growing season.

\section{Methods and Procedures}

Twenty snakeweed plants, selected at random on each of the three areas, were numbered and permanently marked with wooden stakes on June 23, 1977. Measurement of height, maximum and minimum crown diameters were taken on the same 20 plants per site biweekly through the growing season to mid-October. A final 1977 measurement was taken in early December to record changes in height and crown diameters in winter. In May 1978, another set of 20 plants per site were selected at random and marked. Height and crown diameter measurements on these plants were taken biweekly through the growing season to mid-October.

When height and diameter measurements of the 60 plants were taken in 1977, an additional 10 plants on each site were selected at random, measured, and then clipped at ground level and taken to the laboratory for processing. Another clipping was done in early December. The clipping study was not continued in 1978.

In the laboratory, five of the ten harvested plants per site from each clipping date were selected at random. Each of the five plants was individually hand-separated into green leaves, green branches, brown leaves, brown branches, and flower parts (when present). Each separated plant part was kept in individually marked paper bags. All harvested material, including the separated plant material, was oven-dried at $66^{\circ} \mathrm{C}$. Dried components were allowed to equilibrate to normal laboratory temperature and relative humidity and then weighed individually to the nearest decigram. The procedure was repeated for all clipping dates in 1977.

Canopy volumes were calcuated from height and diameter measurements using the formula $\left(4 / 3 \pi a^{2} b\right.$, where $a=$ radius and $b=$ height) for an upper half spheroid as given by Ludwig et al. 1975. Since the canopy data involved successive snakeweed canopy measurements of the same plants during the growing season, analysis of variance was conducted as a split plot in time or with repeated measurements (Steel and Torrie 1960). Protected Least Square Difference (LSD) procedure was used to compare treatment means of canopy volume and plant parts among sites and dates. Data from harvested plants were analyzed in a stepwise regression analysis to obtain relationships between biomass and canopy dimensions. Canopy dimensions of height, diameter and volume were independent variables and biomass was the dependent variable with procedures similar to those described by Rittenhouse and Sneva (1977) for big sagebrush.

\section{Results and Discussion}

\section{Seasonal Volume Changes}

Growth patterns of snakeweed plants varied among areas
1978
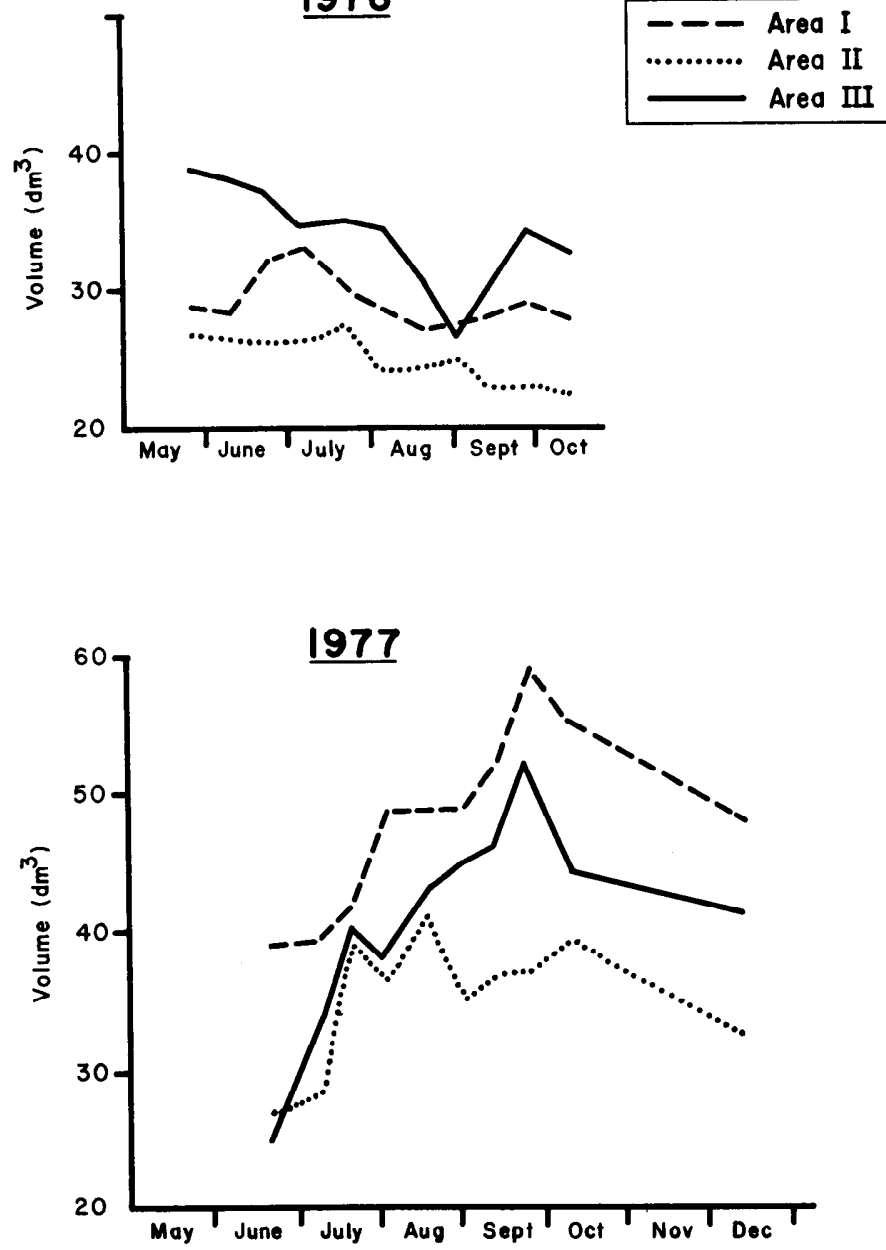

Fig. 1. Average snakeweed canopy volume during the growing season in 1977 and 1978 at three locations.

and between years (Fig. 1). In 1977, canopy volume generally increases through July, August and September, except at Area II where canopy volume increases little after midJuly. This difference probably accounts for the significant area $X$ date interaction in the analysis of variance (Table 1). After September, there appeared to be a decline in canopy volume until the final measurement in December. Soils at Area II were slightly shallower than those on the other areas and may account for the lower growth rate of broom snakeweed plants there.

Conditions in 1978 were in sharp contrast to those in 1977. The general trend appeared to be a decline or static conditions in canopy volume from May through September on all areas (Fig. 1). The nonsignificant $(P>.10)$ area $X$ date

Table 1. Analysis of variance for snakeweed canopy volumes in 1977 and 1978.

\begin{tabular}{lrcrrr}
\hline & \multicolumn{2}{c}{1977} & & \multicolumn{2}{c}{1978} \\
\cline { 2 - 3 } \cline { 5 - 6 } Source & DF & Mean squares & & DF & Mean squares \\
\hline Area (A) & 2 & $192,750^{*}$ & & 2 & 77,263 \\
Error (a) & 57 & 70,550 & & 57 & 88,474 \\
Date (D) & 9 & $28,282^{* * *}$ & & 10 & $4,684^{* * *}$ \\
A X D & 18 & $4,097^{* * *}$ & & 20 & 808 \\
Error (b) & 513 & 893 & & 570 & 598 \\
\hline
\end{tabular}

$* P<0.10$

$* * * P<0.01$ 
interaction indicated that the trend was consistent among the three areas.

These contrasting patterns are probably related to differences in precipitation distribution in the two years. Although precipitation was generally low in May and June in 1977, especially at Area I, 52 to $68 \mathrm{~mm}$ fell in July at the three areas and over $20 \mathrm{~mm}$ in August (Nadabo 1978). In 1978 , conditions were very dry in July when less than $15 \mathrm{~cm}$ fell at each site (Nadabo 1978). Fairly heavy amounts of rainfall (from 40 to $60 \mathrm{~cm}$ ) occurred in late August and during September and probably accounted for the slight upturn in the curves in Figure 1 late in the growing season. Generally, growth patterns followed precipitation patterns; however, the decline in canopy volume on Area II in 1977 cannot be explained by precipitation measurements made.

These data indicate that growth patterns of broom snakeweed are very erratic. Growth patterns may vary from one area to another over fairly short distances and among years. Such erratic growth patterns make planning chemical control very difficult. Additional information is needed to isolate and identify specific phenological stages or soil water conditions when the plants are most susceptible to herbicides.

\section{Biomass of Plant Parts}

Brown branches were the single largest aboveground biomass component, ranging from about $40 \%$ to $80 \%$ of the total canopy for these plants (Table 2). There were few significant differences $(P<0.05)$ among the plants at the different areas in proportion of brown branches and no consistent seasonal trends.

Table 2. Percent dry weights of broom snakeweed aboveground component parts in 1977.

\begin{tabular}{llllcl}
\hline \hline \multicolumn{1}{c}{ Date } & $\begin{array}{l}\text { Brown } \\
\text { branches }\end{array}$ & $\begin{array}{l}\text { Green } \\
\text { branches }\end{array}$ & $\begin{array}{l}\text { Floral } \\
\text { parts }\end{array}$ & $\begin{array}{c}\text { Brown } \\
\text { leaves }\end{array}$ & $\begin{array}{l}\text { Green } \\
\text { leaves }\end{array}$ \\
\hline June 23 & $52^{\mathrm{ab} 1}$ & $28^{\mathrm{a}}$ & $0^{\mathrm{a}}$ & $8^{\mathrm{ab}}$ & $11^{\mathrm{b}}$ \\
July 7 & $58^{\mathrm{a}}$ & $19^{\mathrm{ab}}$ & $0^{\mathrm{a}}$ & $11^{\mathrm{a}}$ & $11^{\mathrm{b}}$ \\
July 21 & $69^{\mathrm{a}}$ & $16^{\mathrm{b}}$ & $0^{\mathrm{a}}$ & $6^{\mathrm{b}}$ & $9^{\mathrm{bc}}$ \\
August 4 & 54 & $26^{\mathrm{a}}$ & $0^{\mathrm{a}}$ & $8^{\mathrm{ab}}$ & $13^{\mathrm{a}}$ \\
August 19 & $46^{\mathrm{b}}$ & $26^{\mathrm{a}}$ & $0^{\mathrm{a}}$ & $9^{\mathrm{a}}$ & $15^{\mathrm{a}}$ \\
September 3 & $48^{\mathrm{ab}}$ & $20^{\mathrm{ab}}$ & $2^{\mathrm{a}}$ & $11^{\mathrm{a}}$ & $18^{\mathrm{b}}$ \\
September 15 & $52^{\mathrm{ab}}$ & $25^{\mathrm{a}}$ & $8^{\mathrm{b}}$ & $6^{\mathrm{b}}$ & $9^{\mathrm{bc}}$ \\
September 29 & $63^{\mathrm{a}}$ & $17^{\mathrm{b}}$ & $7^{\mathrm{b}}$ & $7^{\mathrm{b}}$ & $6^{\mathrm{c}}$ \\
October 14 & $54^{\mathrm{a}}$ & 20 & $4^{\mathrm{ab}}$ & $10^{\mathrm{a}}$ & $9^{\mathrm{bc}}$ \\
December 5 & $63^{\mathrm{a}}$ & $17^{\mathrm{b}}$ & $6^{\mathrm{b}}$ & $10^{\mathrm{b}}$ & $6^{\mathrm{c}}$ \\
\hline
\end{tabular}

'Means within columns followed by different letters are significantly different $(P<0.05)$

Green branches contributed from about 10 to $30 \%$ of the aboveground biomass and showed few seasonal differences except Area I where green branch biomass was rather erratic seasonally and followed precipitation rather closely.

Green leaves and flower parts contributed the smallest proportion of canopy biomass (Table 2). Green leaf biomass apparently reached a peak during August and early September 1977 , when canopy volume was the greatest. Apparently, new leaves were being formed at a greater rate than that of green leaves turning brown during this period. Flower parts were not present until early September when flowering was initiated at all sites. Flower parts never contributed more than $13 \%$ of canopy biomass and exceeded $8 \%$ only during September at Area III.

Problems involved in these compartmental analyses relate to lack of flow rate measurements into and out of the
Table 3. General model and individual site models for estimating aboveground biomass of snakeweed plants in 1977.

\begin{tabular}{llll}
\hline \hline Area & \multicolumn{1}{c}{ Equations $^{1}$} & $\mathrm{R}^{2}$ \\
\hline I & $\mathrm{B}=-118.8+.69 \mathrm{HD}^{2} .53$ & .53 \\
II & $\mathrm{B}=69.3+.011 \mathrm{HD}^{2} .67$ & .67 \\
III & $\mathrm{B}=39.9+0.12 \mathrm{HD}^{2}$ & .69 \\
General & $\mathrm{B}=93.9+.012 \mathrm{HD}^{2}$ & .60 \\
\hline
\end{tabular}

$\mathrm{B}$ is estimated biomass in decigrams, $\mathrm{H}$ is height and $\mathrm{D}$ is diameter.

compartments. Direct measurement of new leaf formation was not made nor was transfer of brown leaves to the litter compartment. More detail analyses of these transfers are needed to construct an overall flow diagram of these processes.

\section{Relationship between Biomass and Canopy Dimensions}

Regression analyses of dimensions (independent variable) with canopy biomass (dependent variable) did not show strong relationships (Table 3 ). The highest $R^{2}$ value was 0.69 at the Area III, indicating that almost $70 \%$ of variation in total canopy biomass could be explained by variation in canopy dimensions. $R^{2}$ values were generally lower for predicting percentages of brown or green branches, green leaves and flower parts (Nadabo 1978), indicating that these compartments are quite variable and not necessarily related to plant size. The different equations for the three areas indicate that it may be difficult to develop a general equation which would have wide application. Ludwig et al. (1975) reported $R^{2}$ values between 0.96 and 0.98 for equations predicting stem and leaf biomass from canopy volume. Apparently, the plants used in their study were more uniform than those used in our study.

Table 4. Estimated snakeweed biomass at times of minimum and maximum growth during 1977 and 1978.

\begin{tabular}{|c|c|c|c|c|c|c|}
\hline \multirow[b]{2}{*}{ Date } & \multicolumn{2}{|c|}{ Arca I } & \multicolumn{2}{|c|}{ Area II } & \multicolumn{2}{|c|}{ Area III } \\
\hline & g/plant & $\mathrm{Kg} / \mathrm{Ha}$ & g/Plant & $\mathrm{Kg} / \mathrm{Ha}$ & g/ Plant & $\mathrm{Kg} / \mathrm{Ha}$ \\
\hline $6-23-77$ & 56.4 & 4126 & 42.1 & 2582 & 38.8 & 2192 \\
\hline $9-29-77$ & 80.7 & 5904 & 53.6 & 3287 & 72.3 & 4084 \\
\hline $12-5-77$ & 68.2 & 4989 & 48.0 & 2944 & 58.9 & 3327 \\
\hline $6-23-78$ & 47.9 & 3504 & 41.0 & 2514 & 53.8 & 3039 \\
\hline $9-29-78$ & 45.3 & 3314 & 37.7 & 2312 & 50.3 & 2842 \\
\hline
\end{tabular}

Snakeweed biomass varied from almost, $6,000 \mathrm{~kg} / \mathrm{ha}$ on Area I to $2200 \mathrm{~kg} /$ ha on Area III (Table 4). These values were calculated using snakeweed density at each area in fall 1977 , and the average biomass per plant from those harvested in the field. These biomass values are high compared to those reported by Rippel (1978) and Tober (1978) for an area near Capitan, New Mexico. However, Tober (1978) reported biomass as high as $1,300 \mathrm{~kg} / \mathrm{ha}$ on areas with lower densities than those on these study areas. Ueckert (1979) reported aboveground biomass for broom snakeweed of almost $2,400 \mathrm{~kg} /$ ha for a population in its second growing season and almost $2,500 \mathrm{~kg} / \mathrm{ha}$ for the same population in its second growing season and almost $2,500 \mathrm{~kg} / \mathrm{ha}$ for the same population in its third growing season in a shortgrass prairie in Lubbock County, Texas. Such high snakeweed biomass suggests fairly high utilization of water and mineral resources by these populations. This likely reduces resources available for other plant species on these sites. Ueckert (1979) reported a $324 \%$ increase in production of shortgrass following complete control of dense stands of broom snakeweed 
and that soil water depletion was greater on rangeland free from snakeweed compared to heavily infested rangeland.

Broom snakeweed appears to be a variable species not only in taxonomic characteristics, but also in ecological amplitude. Apparently the species can tolerate a wide range of conditions and is adaptable to changing environmental conditions. Additional research is needed to explore conditions favoring emergence, establishment and growth of snakeweed. A thorough knowledge of the ecology of broom snakeweed could lead to more effective control or management of this noxious rangeland weed.

\section{Literature Cited}

Buffington, L.C., and C.H. Herbel. 1965. Vegetational changes on a semidesert grassland range from 1858 to 1963. Ecol. Monogr. 35: 139-164.

Campbell, R.S., and E.H. Bomberger. 1934. The occurrence of Gutierrezia sarothrae on Bouteloua eriopoda ranges in southern New Mexico. Ecol. 15: 49-61.

Correll, D.S., and M.C. Johnston. 1970. Manual of the Vascular Plants of Texas. Texas Research Foundation, Renner, Texas. 1574 p.

Dollahite, J.W., and W.V. Anthony. 1957. Poisoning of cattle with Gutierrezia microcephala, a perennial broomweed. J. Amer. Vet. Ass. 130: 525-530.

Dollahite, J.W., T. Shaver, and Bennie J. Camp. 1962. Injected saponins as abortifacients. Amer. J. Vet. Res. 23: 1261-1263.

Hamilton, J.W., and O.A. Beath. 1963. Uptake of available selenium by certain range plants. J. Range Manage. 16: 261-265.

Herbel, C.H., P.L. DIttberner, and T.S. Bickle. 1970. A quantitative ecology of the Jornada Experimental Range. In: Wright, R.G. and G.M. Van Dyne (Eds). Simulation and Analysis of Dynamics of a Semidesert Grassland. Range Sci. Dep. Sci. Series 6. Colorado State Univ., Fort Collins. p. I-133-I-178.
Jameson, D.A. 1970. Value of broom snakeweed as a range condition indicator. J. Range Manage. 23: 302-304

Kingsbury, J.M. 1964. Poisonous plants of the United States and Canada. Prentice-Hall, Inc., Englewood Cliffs, New Jersey. 626 p.

Ludwig, J.A., J.F. Reynolds, and Paul D. Whitson. 1975. Size-biomass relationships of several Chihuahuan desert shrubs. Amer. Midl. Natur. 94: 451-461.

Nadabo, Samu I. 1978. Growth patterns of broom snakcweed (Xanthocephalum sarothrae [Pursh] Shinners) in southern New Mexico. M.S. Thesis. New Mexico State Univ., Las Cruces. 67 p.

Paulsen, H.A., and F.N. Ares. 1962. Grazing values and management of black grama and tobosa grasslands and associated shrub ranges of the Southwest. U.S. Dep. Agr. Tech. Bull. 1270. 56 p.

Pieper, Rex D. 1967. Broomweed problems and control. 12th Annu. Cattle Growers Short Course. New Mexico State Univ., Las Cruces. p. 38-41.

Range Plant Handbook. 1937. U.S. Forest Service, Washington, D.C 370 p.

Rippel, Paul B. 1978. Cabling in the pinyon-juniper ranges of south-central New Mexico. M.S. Thesis. New Mexico State Univ., Las Cruces. 103 p.

Rittenhouse, L.R., and F.A. Sneva. 1977. A technique for estimating big sagebrush production. J. Range Manage. 30: 68-70.

Schmutz, E.M. and D.E. Little. 1970. Effects of 2,4,5-T and picloram on broom snakeweed control in Arizona. J. Range Manage. 23: 354-357.

Talbot, M.W. 1926. Indicators of southwestern range conditions. U.S. Dep. Agr. Farmers Bull. 1782. 36 p.

Tober, D.A. 1978. Broom snakeweed control and vegetative response of blue grama rangeland following application of four herbicides. M.S. Thesis. New Mexico State Univ., Las Cruces. 69 p.

Ueckert, D.N. 1976. Effect of perennial broomweed on grass production. In Sosebee, R.E. and H.A. Wright (Eds.) Noxious Brush and Weed Control Highlights 7: 26. Texas Tech Univ., Lubbock.

Ueckert, D.N., and D.E. Foster. 1976. Insects associated with perennial broomweed. In: Sosebee, R.E. and H.A. Wright (Eds.). Noxious Brush and Weed Control Highlights 7: 24-25. Texas Tech. Univ., Lubbock.

Ueckert, D.N. 1979. Broom snakeweed: effect on shortgrass forage production and soil water depletion. J. Range Manage. 32: 216-220.

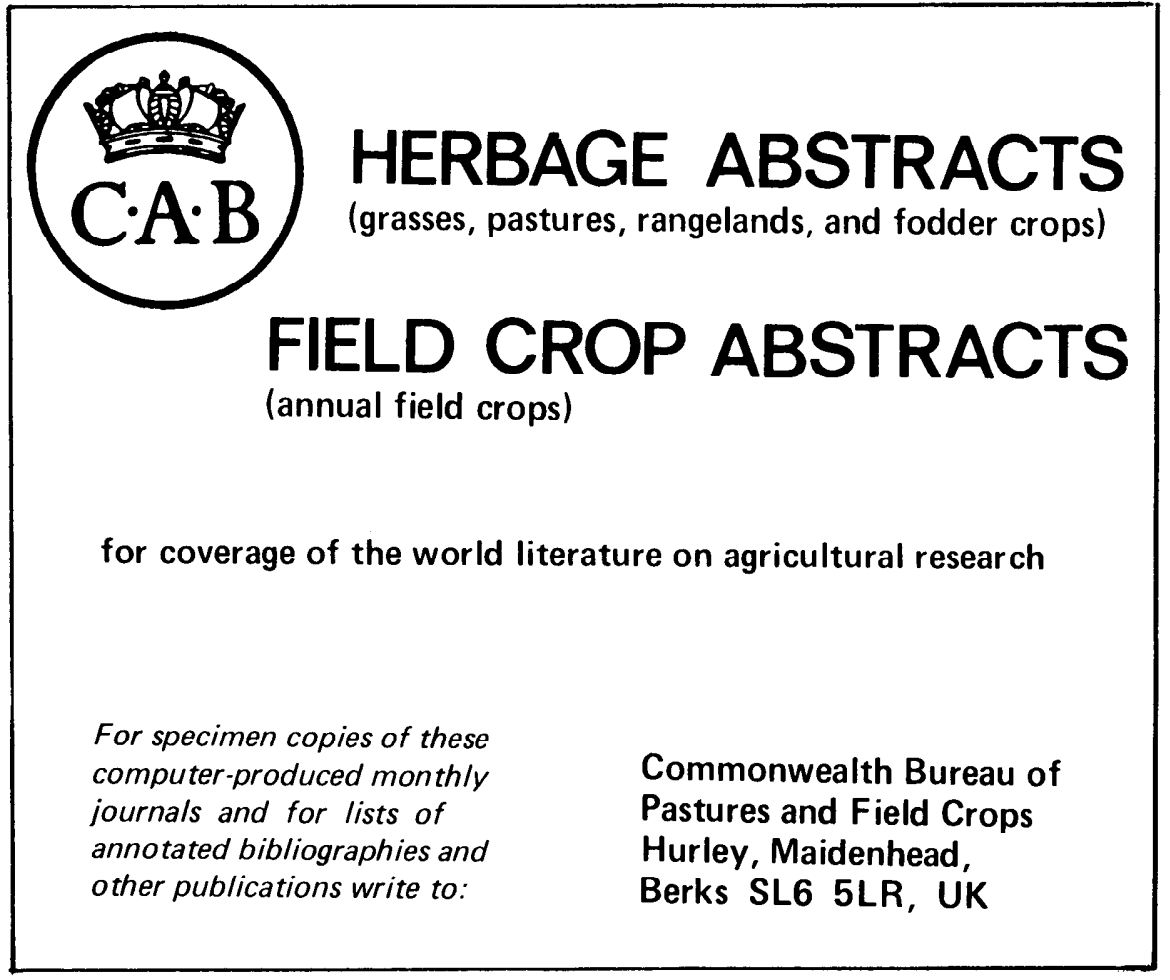

